\title{
Review of Survey activities 2004
}

Edited by

Martin Sønderholm and A.K. Higgins 


\section{Geological Survey of Denmark and Greenland Bulletin 7}

\section{Keywords}

Geological Survey of Denmark and Greenland, survey organisations, current research, Denmark, Greenland.

\section{Cover photographs from left to right}

1. Trenches in chalk at Stevns, Denmark, for acid leaching experiments simulating the reaction of hydrochloric acid in horizontal wells in North Sea chalk reservoirs. Photo: Peter Frykman.

2. As part of the GreenIce project, sea-ice thickness in the Arctic Ocean was measured using airborne helicopter-based electromagnetic profiling in 2004. The project is funded by the EU and carried out in co-operation between the Geological Survey of Denmark and Greenland (GEUS) and the Alfred-Wegener-Institute for Marine and Polar Research (AWI) as well as other research institutes. Photo: Sibylle Goebell, AWI.

3. Investigations related to geological storage of $\mathrm{CO}_{2}$ from fossil fuels are becoming an increasingly important field of work for GEUS. Photo: Peter K. Warna-Moors.

4. Geophysical investigations of the fault-related gold occurrences on the island of Storø, not far from Nuuk, the capital of Greenland (see article on page 65). Photo: Peter W.U. Appel.

\section{Frontispiece: facing page}

The goldmine at Nalunaq, South Greenland. The mine opened in 2004 after more than ten years of intensive geological and technical investigations. Photo: Sven Monrad Jensen.

Chief editor of this series: Adam A. Garde

Scientific editors: Martin Sønderholm and A.K. Higgins

Editorial secretaries: Esben W. Glendal and Birgit Eriksen

Illustrations: Jette Halskov

Lay-out and graphic production: Annabeth Andersen

Printers: Schultz Grafisk, Albertslund, Denmark

Manuscripts submitted: 7 December 2004 - 25 February 2005

Final versions approved: 1 April 2005

Printed: 29 July 2005

ISSN 1604-8156

ISSN 1603-9769

ISBN 87-7871-164-9

\section{Geological Survey of Denmark and Greenland Bulletin}

The series Geological Survey of Denmark and Greenland Bulletin replaces Geology of Denmark Survey Bulletin and Geology of Greenland Survey Bulletin.

\section{Citation of the name of this series}

It is recommended that the name of this series is cited in full, viz. Geological Survey of Denmark and Greenland Bulletin. If abbreviation of this volume is necessary, the following form is suggested: Geol. Surv. Den. Green. Bull. 7, 80 pp.

\section{Available from}

Geological Survey of Denmark and Greenland (GEUS)

Øster Voldgade 10, DK-1350 Copenhagen K, Denmark

Phone: +45381420 00, fax: +45381420 50, e-mail: geus@geus.dk

or

Geografforlaget ApS

Rugårdsvej 55, DK-5000 Odense C, Denmark

Phone: +45634416 83, fax: +4563441697, e-mail: go@geografforlaget.dk

() Danmarks og Grønlands Geologiske Undersøgelse (GEUS), 2005 

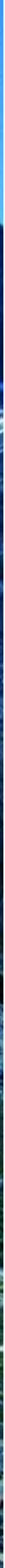

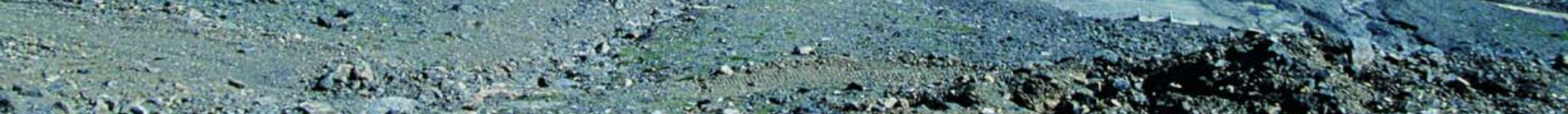

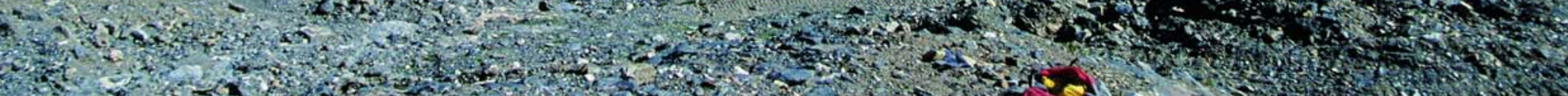
G6.

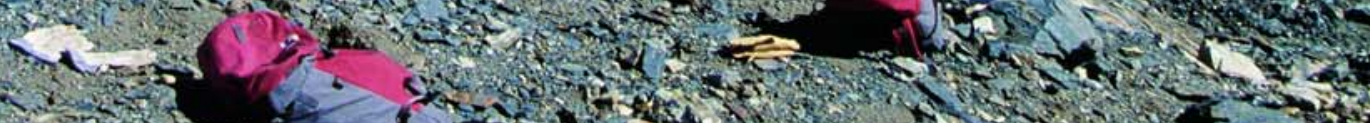

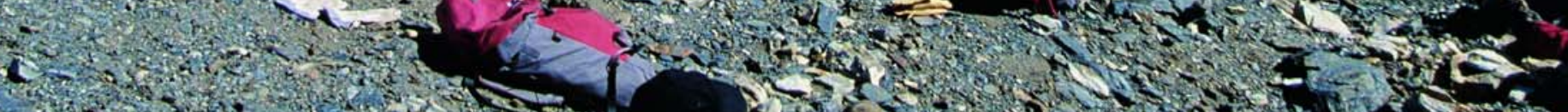

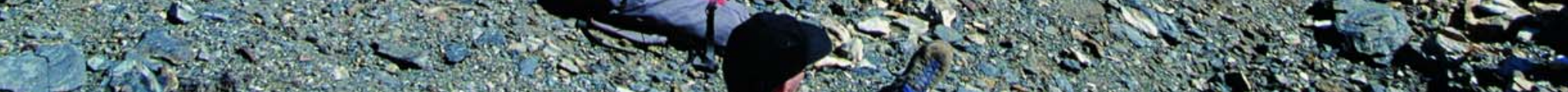

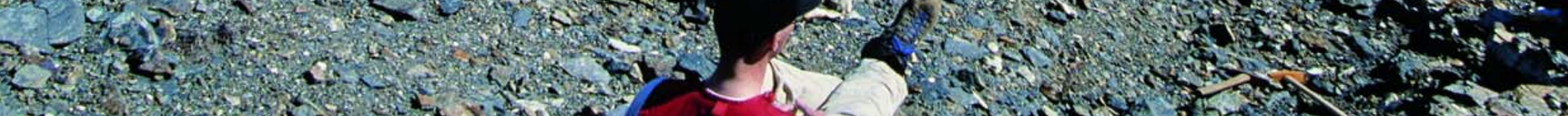

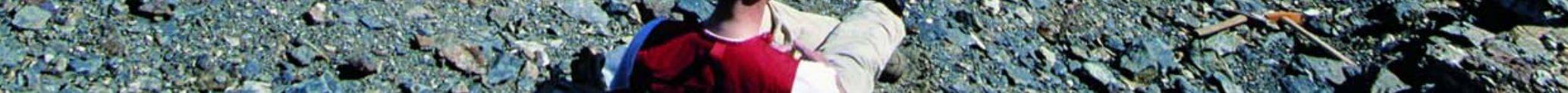
6.th

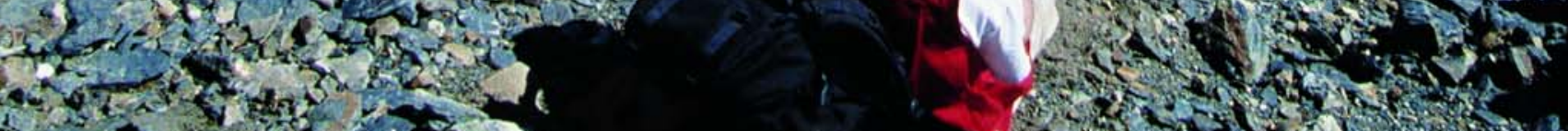

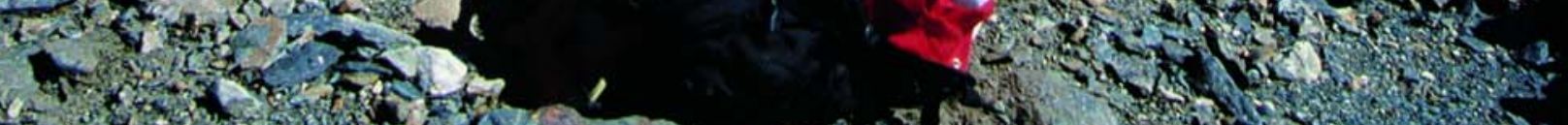

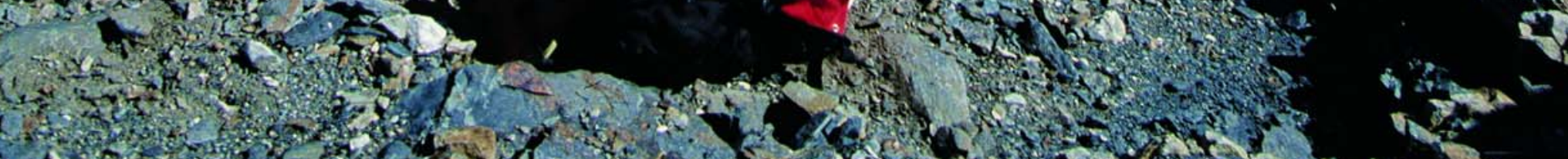




\section{Contents}

GEUS working areas 2004. Orange areas are covered in this volume.

\section{Review of Survey activities 2004}

K. Sørensen

Oil generation from coal source rocks: the influence of depositional conditions and stratigraphic age

Identification of hydrocarbons in chalk reservoirs from surface seismic data: South Arne field, North Sea

P. Japsen, A. Bruun, I.L. Fabricius and $\mathrm{G}$. Mavko

Forward modelling of seismic response from North Sea Chalk

\section{A revised lithostratigraphy for the Paleogene - lower Neogene of the Danish North Sea}

P. Schiøler, J. Andsbjerg, O.R. Clausen,

G. Dam, K. Dybkjær, L. Hamberg,

C. Heilmann-Clausen, L.E. Kristensen,

I. Prince and J.A. Rasmussen

Seismology: neotectonics and structure of the Baltic Shield

S. Gregersen, M. Glendrup, T.B. Larsen,

P. Voss and H.P. Rasmussen

New methods in provenance studies based on heavy minerals: an example from Miocene sands in Jylland, Denmark

C. Knudsen, D. Frei, T. Rasmussen,

E.S. Rasmussen and R. McLimans

Groundwater quality monitoring in Denmark

21 J. Stockmarr 
Quantifying the relationship between pollen sedimentation in lakes and land cover using historical maps

A.B. Nielsen

Climatic warming: a trigger for glacial iceberg surges ('Heinrich events') in the North Atlantic?

A. Kuijpers, H. Heinrich and M. Moros

On-line presentation of mineral occurrences in Greenland

L. Thorning, L.Aa. Christensen, B.M. Nielsen,

F. Schjøth and H. Stendal

Precambrian mineralising events in central West Greenland $\left(66^{\circ}-70^{\circ} 15^{\prime} \mathrm{N}\right)$

H. Stendal and A.A. Garde

Greenstone belts in the central Godthåbsfjord region, southern West Greenland

J.A. Hollis, J.A.M. van Gool, A. Steenfelt and A.A. Garde

Detection of kimberlitic rocks in West Greenland using airborne hyperspectral data: the HyperGreen 2002 project

$\mathrm{T}$. Tukiainen and L. Thorning

Field experimental design for pesticide leaching - a modified large-scale lysimeter

\section{Prospecting for dimension stones} in Greenland

B. Nilsson, J. Aamand, O.S. Jacobsen and R.K. Juhler

T.V. Rasmussen and H.K. Olsen

The Storebrelt gateway to the Baltic

J.B. Jensen, O. Bennike, W. Lemke and A. Kuijpers

Small-scale mining - hazards and opportunities in Kyrgyzstan and Mongolia

P.W.U. Appel 


\title{
Review of Survey activities 2004
}

\author{
Kai Sørensen \\ Director
}

In this second issue of Review of Survey activities the main themes of the Survey's work in Denmark, Greenland and elsewhere are presented for a professional, but not specialist readership. Out of 18 articles, five report on Greenland activities, and this reflects the obligation of the Survey to spend approximately $30 \%$ of its Finance Law grant on Greenlandrelated activities.

The first four articles deal with petroleum-related matters and illustrate some of the pertinent questions concerning the prospective part of the North Sea. Although most oil generated in the North Sea has its origin in marine shales of Late Jurassic age, oil and condensate have also been generated from paralic, coal-bearing sediments of Middle Jurassic age. Most hydrocarbons in the Danish North Sea are found in chalk reservoirs, but Paleocene reservoirs also contribute to Danish oil production; both scenarios are covered by articles in this volume.

As a result of the restructuring of governmental research organisations initiated by the present Danish government, the seismological research - which until 2004 was part of the Danish National Survey and Cadastre - has been moved to the Geological Survey of Denmark and Greenland (GEUS). The seismology group signals this move with a contribution to this year's review concerning the Baltic Shield, of which eastern Denmark forms a marginal part.

GEUS has responsibility for monitoring groundwater quality throughout Denmark. This responsibility carries with it an obligation for research into the processes affecting groundwater quality. This is an important field of research in a country with widespread and intensive agricultural activities, and that relies almost exclusively on groundwater for its water supply. A group of three reports in this volume witness to the range of important activities carried out by the departments of the Survey working with ground water.

Quaternary research at the Survey is presented in three articles that cover vegetation history, the evolution of the Baltic following the last deglaciation and climate research in the North Atlantic. The articles describing marine geology activities build on a long-standing co-operation between
GEUS and the Baltic Sea Research Institute in Warnemünde, Germany.

The Survey's activities in Greenland in 2004 were concentrated in West Greenland. Three papers focus on investigations related to the mineral potential of the Precambrian basement terranes, while one covers the possibility of exploiting dimension stones suitable for the international market. Such studies cannot be carried out without a thorough regional knowledge of the geology of Greenland. In 2004 GEUS reached a milestone in regional geological mapping of Greenland when the last of 14 bedrock geology maps at 1:500 000, which together cover all of Greenland's ice free land areas, was published. The Survey's activities in Denmark and Greenland have now reached a similar stage, in the sense that in both countries resources spent on systematic mapping projects have now become subordinate to more focused activities.

Although the systematic regional mapping of Greenland has reached its primary goal, this is not recorded by a separate article, and there are other activities in GEUS' broad portfolio of tasks that, for one reason or another, are not covered by articles in this volume; to mention a few: Greenland petroleum geology both on- and offshore; surveys adjacent to the Faroe Islands and Greenland directed towards the continental shelf project; ongoing mapping in Greenland and Denmark; projects relating to nationwide modelling of groundwater flow; work on geothermal resources and $\mathrm{CO}_{2}$ sequestration. Furthermore, the important activities dealing with data handling and the creation of new data in GEUS laboratories are not described as such. How these activities ultimately come together to the benefit of the general public and industry is, however, illustrated by the paper on on-line presentation of mineral occurrences in Greenland.

During 2004, GEUS carried out work in more than 20 countries outside Denmark, Greenland and the Faroe Islands (see map in table of contents in this issue). One such project related to small-scale mining in Mongolia and Kyrgyzstan is described. Information on the Survey's activities not dealt with in this volume can be found on the GEUS website. 